\title{
Cinema como lugar de memória: reflexões a partir de filmes amadores Super-8 retomados no curta Supermemórias Maíra Magalhães Bosi ${ }^{1}$
}

Imersa em um processo de constantes transformações visuais, a cidade de Fortaleza (Ceará, Brasil) experimenta, já há algumas décadas, um crescimento urbano acelerado e desordenado ${ }^{2}$. Ainda nos dias atuais, não são raras, por exemplo, as demolições de construções antigas com objetivo de darem lugar a novos prédios, cada vez mais altos. Em nome de um futuro que nunca chega, percebemos que há uma desvalorização do passado desta cidade, com escassas iniciativas públicas de manutenção de lugares, como praças, monumentos e construções, onde a memória de Fortaleza e de seus habitantes possa estar ancorada.

Dirigido pelo cineasta cearense Danilo Carvalho, o curtametragem ensaístico Supermemórias ${ }^{3}$ (2010) reage criativamente a esse movimento de transformações intensas em Fortaleza e propõe a elaboração de Mais uma memória para uma cidade sem lembranças ${ }^{4}$. O curta é composto, exclusivamente, por filmes Super-8 pertencentes a acervos particulares de dezenas de famílias de Fortaleza. Tal material bruto é formado por cerca de 400 rolos Super-8 emprestados por mais de 40 famílias dessa cidade em resposta a uma chamada pública de Carvalho que durou, aproximadamente, dois anos. Apesar de focalizarem acontecimentos tipicamente familiares as imagens contidas nesses filmes também registram a cidade como pano de fundo.

Neste artigo, inspiramo-nos no pensamento do historiador francês Pierre Nora (1984) acerca da noção de "lugares de memória" e procuramos repensá-la no campo do cinema, a partir de questões que emergem do curta Supermemórias. As reflexões aqui ensaiadas buscam compreender a retomada desses filmes Super-8 como possibilidade de criação de um lugar de memória para Fortaleza. Destacamos que o presente trabalho se inscreve em uma pesquisa mais ampla ${ }^{5}$, onde pudemos analisar um extenso corpus de filmes retomados em Supermemórias. Já no âmbito deste artigo, focalizaremos, especificamente, dois

\footnotetext{
${ }^{1}$ Universidade Federal do Rio de Janeiro, Rio de Janeiro - RJ, 21941-901, Brasil.

${ }^{2}$ À semelhança de outras metrópoles contemporâneas.

${ }^{3}$ Disponível em https://vimeo.com/35252608

${ }^{4}$ Subtítulo inicial de Supermemórias que foi substituído, na montagem, por Cabeça, olho, coração - em uma referência ao fotógrafo Henri Cartier-Bresson.

${ }^{5}$ Da qual derivou a dissertação de mestrado intitulada Filmes de família e construção de lugares de memória: Estudo de um material Super-8 rodado em Fortaleza e de sua retomada em "Supermemórias", realizada sob orientação da Profa. Dra. Anita Leandro, e defendida na Escola de Comunicação da Universidade Federal do Rio de Janeiro, em março de 2016.
} 
filmes Super-8 que foram rodados pelo cineasta amador Hélio Rôla, em 1978, com os quais Carvalho compõe uma das sequências de seu curta. Nesse exercício, entrecruzaremos a montagem desta sequência de $\mathrm{Su}$ permemórias com os filmes originais, os depoimentos de Hélio concedidos para essa pesquisa e, ainda, algumas informações históricas sobre o cenário da referida filmagem. O método analítico aqui apresentado busca explorar a criação de um lugar de memória possível para Fortaleza através da montagem cinematográfica.

Antes, porém, de nos debruçarmos nesta análise, é fundamental dedicarmos as secções iniciais deste artigo a algumas reflexões teóricas acerca do filme Supermemórias, da apropriação que fazemos da noção de "lugares de memória" e, também, de algumas observações sobre a relação entre o gesto do cineasta amador e o que identificamos como desejo de construção de memória. Este percurso reflexivo tem como objetivo apresentar as bases conceituais que sustentarão nossa análise final.

\section{O formato Super-8 e o filme Supermemórias}

Além do incômodo de Carvalho em relação à desvalorização da memória em Fortaleza, traduzido no mencionado subtítulo inicial, outra motivação para a realização de Supermemórias foi pautada por um critério estético: seu interesse pessoal pela plasticidade da imagem Super-8. Assim, como consequência do desejo do diretor de trabalhar apenas com imagens neste formato fílmico, Supermemórias constrói sua narrativa sobre um passado recente de Fortaleza, uma vez que seu material bruto foi produzido, especificamente, entre o final da década de 1960 e o início dos anos 1980. Isto porque, lançado no mercado mundial em 1965, pela Kodak, o Super-8 foi a tecnologia preferencial para uso amador ao longo das duas décadas seguintes - até ser substituída pelo formato VHS, em meados dos anos 1980.

Podemos afirmar que, no período em que a filmagem em Super8 esteve relativamente popularizada, houve um volume de produção de imagens amadoras em movimento jamais observado até então. Dentre outros fatores, tal fato se deve à facilidade de manuseio das câmeras deste formato e ao seu relativo baixo custo. Por conseguinte, o advento do Super-8 também parece ter sido responsável por atrair muitos leigos para a prática da filmagem. Ao refletir sobre a fotografia, em sua obra $A$ câmara clara, originalmente publicada em 1980, Roland Barthes declara que "ver-se a si mesmo (e não em um espelho): na escala da História, esse ato é recente" (Barthes 2015, 19). Se transpusermos a constatação de Barthes para pensar sobre a imagem fílmica, na mesma década de 1980, diremos que tanto ver-se a si mesmo em um filme quanto, especialmente, ver imagens em movimento feitas por si próprio eram atos ainda mais recentes na escala da História. Descompromissados com o rigor técnico da linguagem cinematográfica clássica (que, via de regra, desconheciam), os cineastas amadores da época apropriaram-se do 
formato Super-8 para experimentar livremente e, em especial, registrar pessoas e situações que lhes eram caras.

Neste ponto, cabe esclarecer, brevemente, o que este estudo compreende por cineasta amador, uma vez que há uma ampla discussão acadêmica em torno da dicotomia entre amadorismo e profissionalismo no contexto das práticas artísticas. Em sua tese de doutorado, intitulada A cultura amadora na virada do século XIX: a fotografia de Alberto de Sampaio (Petrópolis/Rio de Janeiro, 1888-1914), Adriana Maria Martins Pereira (2010) reflete sobre essa questão retomando parte do debate que aconteceu em torno da fotografia, no contexto dos fotoclubes, na virada do século XIX. A autora demonstra que, enquanto a produção fotográfica profissional visava o ganho financeiro e, não raro, envolvia muitas pessoas ${ }^{6}$, a fotografia amadora era um empreendimento individual, pautado pelo prazer artístico e sem qualquer relação com o ganho de vida do fotógrafo. Além disso, Pereira destaca que os fotógrafos profissionais comprometiam-se com uma representação o mais fidedigna possível da paisagem, objeto ou personagem retratado, enquanto os amadores exercitavam uma prática fotográfica livre de normas ou de qualquer rigor técnico. Segundo a discussão da época, portanto, havia uma "distinção entre o amador como sendo 'artista' e o profissional como aquele que estava associado apenas à fotografia documental" (Pereira 2010, 69).

Quanto ao campo do cinema, conforme dito anteriormente, o advento do Super-8 proporcionou um acesso inédito à prática da filmagem por pessoas até então leigas. Ou seja, também aqui cabe sinalizarmos que o cineasta amador se opõe ao profissional na medida em que seus filmes resultam de práticas de lazer que não geram renda pelo contrário, conforme Roger Odin (1999) pontua, essa produção demanda uma série de gastos. Além disso, também a prática do cineasta amador não procura seguir parâmetros técnicos nem aplicar a linguagem clássica cinematográfica (a não ser intuitivamente). Entretanto, ao contrário do que a discussão apresentada por Pereira aponta a respeito da prática fotográfica da virada do século XIX, não podemos afirmar que os filmes amadores produzidos em Super-8, entre as décadas de 1960 e 1980, tenham tido, necessariamente, finalidade artística.

Isto se deve, em especial, ao fato de grande parte dessa produção se referir a filmes de família - que, por sua vez, são realizados com a intenção principal de guardar um momento relevante para a história familiar e, com isso, construir memória para esse grupo. Odin (1995) destaca que os filmes de família possuem caráter assaz cotidiano e são resultados de práticas recreativas por pessoas que sequer se consideram cineastas. O mesmo autor frisa que tais características são, inclusive, responsáveis pelo fato de esse tipo de filme ser, frequentemente, considerado fútil, mal feito e entediante $(1995,6)$, razões pelas quais teria

\footnotetext{
${ }^{6}$ Além dos fotógrafos, havia técnicos responsáveis por diferentes etapas do processo de revelação, ampliação e correção da exposição da luz, por exemplo.
} 
ficado à margem das pesquisas sobre a história do cinema, até meados da década de $1990^{7}$.

Além de opor-se ao cineasta profissional pelas questões técnicas já elencadas, compreendemos que o cineasta amador é, também, "aquele que ama verdadeiramente o que faz, conforme a etimologia do termo" (Odin 1999, 47, tradução nossa). São, portanto, pessoas afetivamente motivadas pela possibilidade de registrar sua dimensão de mundo. Entretanto, ao fazerem isso, muitas vezes acabam também gerando um material fílmico com valor histórico.

Sobre essa questão e, especificamente no que se refere à produção amadora em Super-8 no Ceará, o cineasta e pesquisador Firmino Holanda observa que

aprecie-se ou não esses filmes, eles representam um momento histórico que jamais será refeito. Todos os títulos são documentos, assim como a produção digital contemporânea revelará mais claramente no futuro os dias que hoje vivemos. E só isso já é muito (Holanda 2013, 126).

De maneira sincrônica, a pesquisadora Lara Amorim também se volta para a produção amadora em Super- 8 e afirma que um acervo audiovisual cujas imagens foram

produzidas por um determinado grupo social em um dado momento histórico, adquire a característica de um acervo dotado de memória e visibilidade, capaz de revitalizar valores e práticas culturais que correm o risco de serem esquecidas, ou mesmo permanecerem desconhecidas por determinados segmentos sociais (Amorim 2013, 12-13).

No caso do material fílmico Super-8 retomado por Carvalho, percebemos que ele se vincula tanto à memória dos cineastas amadores e das famílias retratadas quanto à da própria cidade onde foi produzido. E, enquanto Fortaleza sofria um processo de profundas transformações visuais, nas últimas décadas, preciosos fragmentos do seu passado permaneceram preservados nas bobinas desses filmes amadores. Contudo, além de dispersas em diferentes casas, as imagens que compõem $\mathrm{Su}$ permemórias também estavam relegadas ao que, à falta de um termo mais preciso, nos convém chamar de exílio técnico, dada a atual obsolescência do Super-8 e o fato de poucas famílias ainda possuírem projetores desse formato em funcionamento. É, portanto, digno de nota o fato desses rolos de filme terem sido mantidos ao longo dos anos a despeito de sua inacessibilidade técnica - evidência do valor afetivo de tais objetos para as famílias.

Carvalho identifica nesses filmes Super-8 potencial para a elaboração daquilo que chamou de "memória coletiva" 8 de Fortaleza e, ao

\footnotetext{
${ }^{7}$ Em 1995, duas importantes obras são lançadas, marcando o início do interesse acadêmico sobre os filmes de família: a coletânea Le film de famille: Usage privé, usage public, organizada por Roger Odin, e Reel Families: A Social History of Amateur Film, de Patricia Zimmerman.

${ }^{8}$ Expressão utilizada por Carvalho no site: www.filmesupermemorias.com.br
} 
convocar esse material fílmico privado para compor uma nova obra cinematográfica, reúne dezenas de acervos familiares em um único arquivo, que forma o material bruto de Supermemórias. Porém, há algo ainda mais potente no gesto do diretor ao reunir tal material fílmico, algo que aponta "na direção de um projeto estético e político implicado na defesa do próprio cinema" (Furtado e Lima 2014, 9). Carvalho devolve movimento a imagens que estiveram adormecidas nessas estreitas películas, impossibilitadas de serem vistas e, assim, também age no sentido de "guardar o cinema da sua condição de desaparecimento" (Furtado e Lima 2014, 9). Em outras palavras, o diretor eleva o cinema à condição de lugar onde tanto a memória de Fortaleza quanto a memória da própria linguagem cinematográfica podem sobreviver. Afinal, a produção de Supermemórias justifica o resgate de centenas de filmes que, provavelmente, jamais seriam vistos novamente e que permaneceriam à margem de qualquer estudo sobre cinema.

A montagem que Carvalho faz com as imagens dos filmes Super8 reunidos se dá por um processo absolutamente conectado à sua subjetividade sendo, em muitos momentos, orientada pelas suas próprias lembranças e referências afetivas em Fortaleza. Dessa forma, Supermemórias representa um entrelaçado de memórias: as dos cineastas amadores e famílias retratadas e as de seu próprio diretor. Apesar da análise da montagem de Supermemórias não constituir objeto deste artigo, gostaríamos de destacar três aspectos estéticos e narrativos desta obra que merecem a nossa atenção pela maneira como se relacionam com a criação de "mais uma memória" para Fortaleza.

O primeiro deles é o fato de Supermemórias apresentar sequências temáticas que evidenciam a repetição dos mesmos assuntos em filmes pertencentes a diferentes acervos familiares da cidade. Logo no início, há uma sequência formada por imagens de diferentes mulheres grávidas, deitadas em leitos de hospital e sorrindo para a câmera enquanto acariciam suas barrigas. E, ao longo do curta, também há sequências de crianças brincando, cerimônias de casamento, festas de aniversário, etc. Assim, a montagem de Supermemórias parece valorizar os acontecimentos familiares recorrentes como parte da memória de Fortaleza.

O segundo aspecto que gostaríamos de abordar se refere à construção sonora de Supermemórias. Dada sua complexidade, essa dimensão mereceria, aliás, uma abordagem mais detalhada, uma vez que a grande maioria dos filmes Super-8 retomados nessa montagem eram, originalmente, mudos. Entretanto, a paisagem sonora que Carvalho cria em seu curta passa longe de ser uma mera tentativa de dublar imagens; pelo contrário, ela propõe uma ressignificação de cenas aparentemente banais. Um exemplo disso é a sequência de festas de aniversário, cujo som que sobressai não é o das palmas ou o do coro de Parabéns para você mas, sim, o do sopro que cada aniversariante dá em sua vela. Ou seja, diante de um tipo de imagem que já foi vista à exaustão, o espectador é convidado a prestar atenção, justamente, ao ruído jamais ouvido em uma festa de aniversário. 
Quanto à forma como a construção sonora criada para Supermemórias se relaciona com a memória de Fortaleza, destacamos uma sequência cujas imagens mostram cenas de familiares reunidos em varandas, quintais e outras áreas externas de diferentes casas. Não por acaso, a trilha sonora que acompanha essas imagens é a cadência de um triângulo, som que remete aos tradicionais ambulantes que circulam a pé pelas ruas de Fortaleza apregoando a venda de biscoitos conhecidos localmente como "chegadim". Importante frisar que esse é um som que pertence ao repertório afetivo de qualquer habitante de Fortaleza e ecoa como "um código há algum tempo compartilhado pela comunidade" (Aragão 2012, 124). Além disso, a projeção sonora desse instrumento "permite aos ambulantes cruzarem limites entre o espaço público e o espaço privado" (Aragão 2012, 124). Portanto, essa sequência de Supermemórias complexifica a relação entre memória pessoal e memória coletiva na medida em que imagens de acontecimentos da esfera privada são acompanhadas por um som que pertence ao imaginário coletivo da cidade.

Por fim, cabe pontuarmos que são poucas as sequências de $S u$ permemórias que mostram, efetivamente, a paisagem urbana de Fortaleza. E, a maior parte daquelas que dão a ver essa cidade, localizam-se no início do curta e mostram, fundamentalmente, os cenários litorâneos dessa cidade. Adiante, analisaremos uma dessas sequências, que mostra jovens pulando em direção ao mar e realizando manobras aquáticas conhecidas localmente como "carretilha”.

\section{Sobre a noção de lugares de memória}

Conforme já aludido, o presente trabalho inspira-se nas proposições de Pierre Nora acerca da noção de "lugares de memória" desenvolvidas na apresentação da coletânea Les lieux de mémoire ${ }^{10}$, da qual é organizador. É fundamental, portanto, reconhecermos que Nora se propõe a pensar essa noção no campo da História e, especificamente, em relação à memória da nação francesa. Porém, a despeito da distância do campo do Cinema, identificamos na ideia de "lugares de memória" um potencial estratégico para reflexões sobre objetos em outros contextos, outras escalas e sob novas perspectivas. Deste modo, neste trabalho, tomamos essa noção para refletirmos sobre a retomada de filmes amadores em uma obra que teve como pretensão construir memória para uma cidade.

Nora argumenta que "os lugares de memória nascem e vivem do sentimento de que não há memória espontânea, de que é preciso criar os arquivos (...) manter os aniversários, organizar as celebrações (...)

\footnotetext{
${ }^{9}$ Um dos nomes dados, em Fortaleza, a um "doce muito fino, feito basicamente de água, farinha de trigo, goma e açúcar, e que é comumente assado em chapas sobre fornos a carvão" (ARAGÃO 2011, 2), que também é chamado de "chegadinho" ou "chegadinha". ${ }^{10}$ Composta por três tomos, em vários volumes, publicados entre os anos de 1984 e 1992, como produto de um seminário mantido pelo historiador entre os anos de 1978 e 1981, na École des Hautes Études en Sciences Sociales (EHESS).
} 
porque essas operações não são naturais" (Nora 1984, XXIV, tradução nossa). Além disso, o autor alerta para o fato de, entretanto, tais lugares permanecerem ameaçados pelo movimento de mudanças na sociedade contemporânea e, por isso, demandarem uma "vigilância comemorativa” (Nora 1984, XXIV, tradução nossa). Tal vigilância, parece-nos, advém de sua dimensão pública, de sua entrada no imaginário coletivo.

No entanto, uma das preocupações de Nora parece estar no reconhecimento de alguns símbolos nacionais como lugares onde a memória coletiva francesa pudesse estar ancorada. Sobre tais símbolos, cabe assinalar que, dentre os exemplos ${ }^{11}$ destacados pelo autor, todos já possuíam uma dimensão coletiva, ou seja, já pertenciam ao imaginário público. Essa observação coloca, assim, um dos principais pontos que merecem atenção ao nos apropriarmos dessa noção para uma análise fora de seu contexto original. Afinal, nosso objeto de estudo se situa numa escala bem menor do que a de Nora: filmes particulares e um curta-metragem de pequeno alcance (que não se tornou ícone da cidade nem está presente no imaginário coletivo). Por outro lado, Supermemórias se destina, sim, à circulação pública ${ }^{12}$ e tal aspecto aproxima essa obra dos demais exemplos trazidos por Nora, permitindo-nos levantar a possibilidade de enxergá-la como lugar de memória para Fortaleza.

Estabelecida essa ressalva inicial, cabe-nos agora dialogar com as proposições de Nora, no intuito de demonstrarmos sob que bases nos apropriamos da noção de "lugares de memória", cuja definição central é:

(...) lugares, com efeito, nos três sentidos da palavra, material, simbólico e funcional, simultaneamente, mas em níveis variados. Mesmo um lugar de aparência puramente material, como um depósito de arquivos, só é lugar de memória se a imaginação o investe de uma aura simbólica. Mesmo um lugar puramente funcional, como um manual de aula, um testamento (...), só entra na categoria se for objeto de um ritual. Mesmo um minuto de silêncio, que parece o exemplo extremo de uma significação simbólica, é ao mesmo tempo o recorte material de uma unidade temporal e serve, periodicamente, para uma chamada concentrada de lembrança. Os três aspectos coexistem sempre (Nora 1984, XXXIV, tradução nossa).

Sem grande esforço, conseguimos enxergar essas três dimensões nos filmes Super- 8 produzidos em âmbito doméstico. Afinal, eles materializam acontecimentos com objetivo de fazê-los perdurar (conforme veremos a seguir) e seu caráter simbólico advém, sobretudo, do próprio desejo de fazer dessas imagens guardiãs de uma memória familiar comum. Além disso, sua dimensão funcional pode ser observada nos rituais de exibição privada aos quais estes filmes servem (e que são, fundamentalmente, a sua razão de existência). Nesses eventos de famí-

\footnotetext{
${ }^{11}$ Citamos alguns: arquivos, associações, comemorações, minuto de silêncio, bandeira e hino nacionais.

${ }^{12} \mathrm{O}$ curta-metragem foi exibido em diversos festivais nacionais e internacionais, cineclubes, etc. Além disso, como referido anteriormente, está disponível online com um link ativo para download.
} 
lia, as imagens projetadas funcionam como catalisadoras de lembranças. E, além disso, por estimularem comentários dos parentes presentes (sobre o passado vivido e registrado), elas também alimentam a construção de uma memória comum desse grupo.

Nora ressalta que devemos compreender lugares "do [sentido] mais material e concreto, como os monumentos aos mortos e os arquivos nacionais, ao mais abstrato e intelectualmente construído, como a noção de linhagem, de geração" (1984, p.VII, tradução nossa). Esse termo, associado à palavra memória, nos parece, sobretudo, propor-se a designar suportes para que a atualização da memória de um grupo possa acontecer - quer sejam suportes construídos com esse propósito, quer tenham adquirido tal função após sua elaboração. Nos filmes Super-8 que formam o objeto desse estudo, percebemos ambos os propósitos: tanto foram realizados para resguardar um momento especial e torná-lo memorável para determinado grupo de pessoas, quanto, com o passar dos anos, suas imagens foram ganhando novas camadas de sentido e, com essa distância temporal, acumulando mais níveis de memória. Assim, parece-nos possível compreender tais filmes como lugares de memória para o grupo de pessoas cujas histórias estão ali retratadas.

Entretanto, no âmbito desta pesquisa, não basta compreender em que medida esses filmes Super- 8 representariam, eles próprios, lugares de memória para os pequenos grupos familiares aos quais se destinam originalmente. Embora seja importante reconhecê-los nessas bases, interessamo-nos, sobretudo, pela reflexão sobre o processo pelo qual suas imagens passam a servir à elaboração de um lugar de memória para essa cidade. Tal movimento ocorre por meio da montagem, pois é a partir desse procedimento cinematográfico que "os filmes domésticos passam a pertencer ao seu tempo histórico" (Blank 2015, 18) e, ao saírem do âmbito restrito da família, "se abrem para o mundo e entram para a memória comum” (Blank 2015, 9). Assim, e em diálogo com os exemplos trazidos por Nora, compreendemos que esses filmes Super- 8 precisaram sair de seu circuito original de apreciação privativa para que, então, pudéssemos falar em uma construção de lugar de memória para a cidade a partir de suas imagens. Conforme demonstraremos nas próximas secções, o gesto criativo de Danilo Carvalho não só traz tais imagens para a esfera pública como, especialmente, reelabora seu sentido.

Com base nestas demarcações iniciais, exploraremos, na sequência, algumas questões teóricas pertinentes à gênese das imagens Super-8 retomadas em Supermemórias. Tal procedimento visa, também, conforme já aludido, compreender esse material fílmico como portador de desejo de memória desde o momento de sua tomada pelo cineasta amador.

\section{O desejo de memória nos filmes amadores}

Na medida em que a criação de uma imagem visa, em última instância, à sua contemplação futura, podemos compreender que tal gesto tem como motivação a possibilidade de apreender um momento vivido para 
que ele possa ser revisitado posteriormente. Nessa perspectiva, a imagem, em si, traduziria um desejo humano de permanência, de uma "necessidade primitiva de vencer o tempo pela perenidade da forma" (Bazin 2014,20 ) e de salvar o instante, fugaz por natureza, de uma segunda morte. Esse pensamento pode ser corroborado pela compreensão de que "a memória se enraíza no concreto, no espaço, no gesto, na imagem, no objeto” (Nora 1984, XIX, tradução nossa). A partir disso, podemos pensar o gesto do cineasta amador como esforço de capturar um momento efêmero para transformá-lo em imagem resguardando-o, assim, na materialidade de um suporte físico - no caso de nosso objeto de estudo, as películas Super-8. Afinal, assim como Barthes observou a respeito da fotografia, um filme também "reproduz ao infinito [algo que] só ocorreu uma vez: (...) repete mecanicamente o que nunca mais poderá repetir-se existencialmente" (Barthes 2015, 14). Eis, então, o que identificamos como a motivação central ${ }^{13}$ dos cineastas amadores que produziram os filmes Super-8 aqui estudados: fazer com que um instante específico (escolhido de acordo com circunstâncias e interesses particulares) possa perdurar "dotado de destino temporal autônomo" (Bazin 2014, 20).

Nesse esforço de fixar o instante e permitir que ele seja revisitado posteriormente, consideramos os filmes Super-8 aqui abordados como "testemunhas de uma outra época, das ilusões de eternidade" (Nora 1984, XXIV, tradução nossa), capazes de atualizar um evento passado no tempo futuro. Eles representam acontecimentos do passado, ou seja, tornam presente a coisa ausente - paradoxo que ajuda a explicar o fenômeno da rememoração (Barbosa 2007). Ao fazerem isso, tais imagens, à primeira vista, podem parecer servir de suporte para o futuro revisitar o passado e, nesse movimento, reencontrar sua memória. Entretanto, não devemos enxergar o movimento da memória como um simples salto para o passado.

Ancorado nas proposições de Walter Benjamin (1985), o pesquisador Maurício Lissovsky argumenta que a memória "não é unidirecional, não é um movimento que surge no presente e se volta para o passado (como sugere a ideia de rememoração), mas sim bidirecional: o passado visa, na mesma medida em que é visado, ao futuro" (Lissovsky 2005, 138). A consideração de Lissovsky pode ser apropriada, neste estudo, nos seguintes termos: apesar de ser inegável que esses filmes Super-8, realizados entre as décadas de 1960 e 1980, despertem interesse sobre o passado (por funcionarem como vestígios), questionamo-nos se não seria possível pensar, a partir deles, também um processo de valorização do futuro.

Assim, perguntamo-nos se essas imagens não estariam tão interessadas em se dirigir ao futuro quanto em, efetivamente, reter um

\footnotetext{
${ }^{13}$ Motivação essa que, obviamente, encontramos em todos aqueles que produzem imagens (sejam fílmicas ou fotográficas) de acontecimentos pertinentes às suas vidas particulares, independentemente do formato tecnológico utilizado.
} 
momento vivido. Em outras palavras, apesar de funcionarem como vestígios do passado, tais filmes talvez nos falem menos sobre a relevância dos acontecimentos que registram e mais sobre uma promessa de futuro, um legado, uma herança dessas famílias aos seus descendentes. Afinal, em que medida dirigir-se ao futuro através de imagens (propositalmente criadas "para ele") não seria também uma forma de antecipá-lo ou, ainda, de construí-lo? Apropriando-nos de outra reflexão de Lissovsky (2005) acerca da memória, também na esteira de Benjamin, não poderíamos considerar a criação dessas imagens como uma maneira de sonhar um futuro irrealizado? E, nesse sentido, ao mesmo tempo em que se dirigem ao futuro, elas também parecem construí-lo, em alguma medida.

Ao considerarmos, porém, que a criação de uma imagem deriva do ímpeto de se fixar um momento para que se possa acessá-lo posteriormente, temos aí um paradoxo interessante, uma vez que o próprio instante é fugaz, além de irreconhecível, senão no futuro. Se as imagens são, de certa forma, criadas para que o instante sobreviva, parece-nos relevante destacar que o instante, ele próprio, só "existe", de fato, no futuro. A partir do filósofo francês Henri Bergson, em Matéria e memória (2006), compreendemos que a própria percepção já é uma antecipação da memória. Assim, apesar de um fato parecer afetar-nos no momento presente, "nós só percebemos, praticamente, o passado, o presente puro sendo o inapreensível avanço do passado a roer o futuro" (Bergson 2006, 176). Embora percebido sensorialmente e, assim, isolado dos momentos que o precedem e o sucedem, o instante sempre nos escapa, pois, cognitivamente, só o reconhecemos depois que ele passou. E, na medida em que "a sensação e a cognição não podem habitar o mesmo instante [...], o presente está sempre perdido” (Charney 2010, 319).

Nesse contexto, o cinema se nos apresenta como lugar privilegiado de apreensão e representação do instante, por fazê-lo através de imagens em movimento. "O eu futuro irrompe no eu passado; o presente é somente essa muda instantânea e incessante [...] O cinema é a única arte que pode representar esse presente como ele é" (Epstein citado em Charney 2010, 326, itálico nosso), ou seja, a imagem cinematográfica não só torna presente algo que já passou como o faz, inclusive, em sua duração. Retomando a já citada reflexão de Bazin sobre a representação de um objeto pela imagem fotográfica, o mesmo autor defende que enquanto a fotografia paralisa e embalsama o tempo,

o cinema vem a ser a consecução no tempo da objetividade fotográfica. O filme não se contenta mais em conservar para nós o objeto lacrado no instante [...]. Pela primeira vez, a imagem das coisas é também a de sua duração, qual uma múmia da mutação (Bazin 2014, 24).

Dessa forma, a imagem em movimento dos filmes nos parece capaz de representar, simbolicamente, a própria fugacidade do instante a partir de sua apreensão. Além disso, conforme Odin $(1999,52)$ destaca a partir de Alain Bergala, é como se a duração da tomada permitisse restituir algo da sensação geral de um momento vivido. 
Conforme já mencionado, os cineastas amadores responsáveis pelos filmes retomados em Supermemórias se apropriaram do aparato Super-8, intuitivamente, com o objetivo principal de apreender e conservar experiências significativas de sua vida pessoal. Em contraste com a maior parte dos acervos fílmicos particulares reunidos por Carvalho, os filmes do cineasta amador Hélio Rôla, que analisaremos detalhadamente adiante, destoam por não apresentarem cenas tipicamente pertencentes ao contexto familiar. Ou seja, nesses filmes, não há qualquer imagem de aniversários, casamentos ou festas de Natal. Aliás, sua câmera sequer mostra acontecimentos em ambientes privados, pelo contrário: aponta exclusivamente para o espaço público. Entretanto, ao entrevistarmos Hélio, compreendemos que sua motivação para filmar correspondia aos critérios afetivos que justificariam a realização de qualquer filme de família. Assim, conforme discutiremos adiante, percebemos que Hélio filmava os acontecimentos da vizinhança como quem filma sua própria família.

Odin declara, em uma de suas passagens, que a única coisa que importa em um filme de família "é que o objeto, o personagem ou o evento em questão tenha sido julgado digno, por aquele que operava a câmera, de figurar na coleção de lembranças familiares" (Odin 1995, 28, tradução nossa). Inspirada nessa declaração, a pesquisadora Lígia Diogo, em sua dissertação de mestrado, intitulada Vídeos de família: entre os baús do passado e as telas do presente (2010), vai além e defende que, então, "mesmo um show dos Beatles ou o assassinato do presidente norteamericano Kennedy podem ser um filme de família"14 (Diogo 2010, 96). Ou seja, essa autora compreende que os assuntos condizentes com o que Odin chama "coleção de lembranças familiares" dizem respeito a acontecimentos relevantes para esse grupo de pessoas, mas não precisam, necessariamente, estar limitados a eventos exclusivamente ligados aos tradicionais rituais ou demais momentos vividos em família. Essa conclusão de Diogo reforça nossa compreensão dos filmes de Hélio como filmes de família. Afinal, este cineasta amador julgou o campeonato ocorrido na Praia de Iracema digno de figurar em seu conjunto particular de lembranças e não realizou essa filmagem com qualquer propósito além de guardar tal recordação para si e para aqueles que aparecem nessas imagens. Nesse sentido, conforme já havíamos antecipado, filmar um campeonato que acontece no bairro se aproxima do impulso de filmar, por exemplo, uma festa de família, visto que ambos os acontecimentos giram em torno da esfera de vida particular e do afeto de quem filma.

Tanto nesses filmes Super-8 de Hélio quanto nos demais reunidos no material bruto de Supermemórias, notamos um equilíbrio frágil entre a precariedade da linguagem cinematográfica e uma certa genuinidade dos assuntos filmados. Dentre outros elementos estéticos que nos permitem

\footnotetext{
${ }^{14}$ A autora faz referência a acontecimentos que, sabidamente, foram filmados por cineastas amadores e acabaram fazendo parte de suas coleções de lembranças particulares, apesar de serem eventos públicos. Como, por exemplo, o assassinato do presidente Kennedy.
} 
perceber isso, destacamos a câmera tremida. Presente na maioria desses filmes amadores, tal característica denota, duplamente, tanto o amadorismo técnico de quem filma quanto o que Odin (1999) pontua como "efeito de autenticidade". Para o autor, as imagens tremidas decorrem do fato de as câmeras serem leves e do uso intuitivo de recursos potentes como o zoom, e, sobre essa questão, provoca: "mas por que a trepidação [da câmera] seria a priori negativa?" (Odin 1999, 57).

Percebemos que esse equilíbrio frágil entre amadorismo técnico e caráter autêntico dos assuntos filmados colabora para a interpretação de filmes amadores como amostras legítimas do passado. No caso dos filmes Super-8 que compõem o material bruto de Supermemórias eles também representam autênticos fragmentos da vida particular de alguns habitantes de Fortaleza. Porém, é importante considerarmos que tais filmes também são construções submetidas ao olhar e ao propósito de quem filma tanto quanto a regras coletivas do quê e como filmar. Aliás, Odin chega a atribuir a própria decisão do cineasta amador de filmar sua família, por exemplo, menos à sua intenção individual do que a uma sugestão exterior, que viria de uma "ideologia familialista ${ }^{15}$ que o atravessa e o constitui” (Odin 1999, 52, tradução nossa). Sem dúvida, os cineastas amadores que realizaram esses filmes Super-8 o fizeram seguindo um impulso pessoal, mas é necessário considerarmos, também, que, em certa medida, eles se sentiram autorizados a apontar suas câmeras para assuntos particulares pelo fato de essa ação também ser socialmente aceita e, até, incentivada.

Assim, cabe pontuarmos que o desejo de memória presente na tomada dessas imagens Super-8, pelos cineastas amadores, não nos parece isolado de um contexto mais amplo da contemporaneidade, no qual se observa uma perda de memória espontânea. Sobre essa questão, Nora destaca:

o sentimento de um desaparecimento rápido e definitivo combina-se à preocupação com o exato significado do presente e com a incerteza do futuro para dar ao mais modesto dos vestígios, ao mais humilde testemunho a dignidade virtual do memorável (Nora 1984, XXVI, tradução nossa).

Dessa forma, é interessante salientar que esses cineastas amadores - intuitiva ou sintomaticamente -, reagem a essa perda de memória espontânea identificada por Nora através da produção de seus filmes Super-8. Essa produção amadora de imagens, no âmbito da vida particular, parece corroborar com a ideia de que

à medida que desaparece a memória tradicional, nós nos sentimos obrigados a acumular religiosamente vestígios, testemunhos, documentos, imagens, discursos, sinais visíveis do que foi, como se esse dossiê cada vez mais prolífero devesse se tornar prova em não se sabe que tribunal da história (Nora 1984, XVII, tradução nossa).

Apesar disso, reconhecemos que esses cineastas amadores não tinham a preocupação de suprir uma lacuna de memória na sociedade,

\footnotetext{
${ }^{15}$ No texto original do autor, em francês, o termo usado é familialiste.
} 
seu objetivo era apenas o de construir, para seu grupo familiar, lembranças que permitissem a "recriação mítica do passado vivido" (Odin 1995, 32, tradução nossa). Porém, nosso olhar e nosso exercício reflexivo sobre essas imagens tornam possível a interpretação desses gestos particulares e intuitivos como pertencentes a um contexto maior - o da já citada perda de memória espontânea na contemporaneidade.

A seguir, ilustraremos com a análise de uma sequência de Supermemórias mediante a qual poderemos explorar um pouco mais as questões anunciadas até aqui. Procuraremos demonstrar, sobretudo, como um registro fílmico, muitas vezes negligenciado como material empírico, pôde, ao despertar o interesse de Carvalho, se conectar à narrativa de uma cidade e contribuir para a preservação e a atualização de sua memória.

\section{Pulo no mar ontem e hoje}

A imagem de um copo descartável com as laterais cortadas em fatias, simulando um catavento de brinquedo, abre essa sequência de Supermemórias. Apoiado no dedo de um homem, o copo-catavento se equilibra e gira por pouco tempo, até ser levado pela brisa. Ao fundo dessa imagem, vemos o mar azul escuro, a linha do horizonte e uma faixa estreita de céu azul clara. Em seguida, vem uma cena com o mesmo pano de fundo onde um homem pedala sob um píer de concreto em ruínas. Também aqui, percebemos a presença do vento intenso, ao balançar vigorosamente uma bandeira velha fincada no chão. A câmera acompanha o movimento do ciclista com uma pan sutil para a esquerda até o corte. De cabeça, um banhista salta deste mesmo píer em direção ao mar e a câmera segue esse movimento até enquadrar, em um leve plongé, o seu mergulho.

No terceiro plano desta sequência, vemos outro homem caminhar sob o mesmo píer em ruínas enquanto carrega uma tábua de madeira com o nome "Sérgio" pintado à mão. O enquadramento aqui é bastante semelhante ao do plano do ciclista, embora a imagem seja mais tremida e instável - o horizonte, por exemplo, aparece torto. O personagem em cena (Sérgio?) olha em direção à câmera e sorri comportamento recorrente nos filmes de família. A montagem segue com mais três planos de jovens jogando tábuas de madeira e pulando para o mar de cima desse mesmo píer que, agora, aparece repleto de espectadores.

Em seguida, vem uma série de planos que mostram manobras aquáticas ao pôr-do-sol: os jovens surfam deitados nas pranchas improvisadas (em uma prática semelhante ao que hoje conhecemos como bodyboard), mergulham, nadam e deixam seus corpos serem levados pela maré. Mais um corte e, fora da água, vemos um jovem vestido com calça, camisa e sapato posando para a câmera enquanto segura um tabuleiro nos ombros (estaria vendendo alguma comida ou apenas simulando?). Finalmente, o último plano dessa sequência registra um 
fotógrafo de perfil e de pé, na beirada no píer. Esse personagem está com o olhar focado na objetiva de sua câmera e, completamente absorto em sua própria ação, parece não perceber estar sendo filmado. Um zoom out revela um segundo píer em ruínas ao fundo.

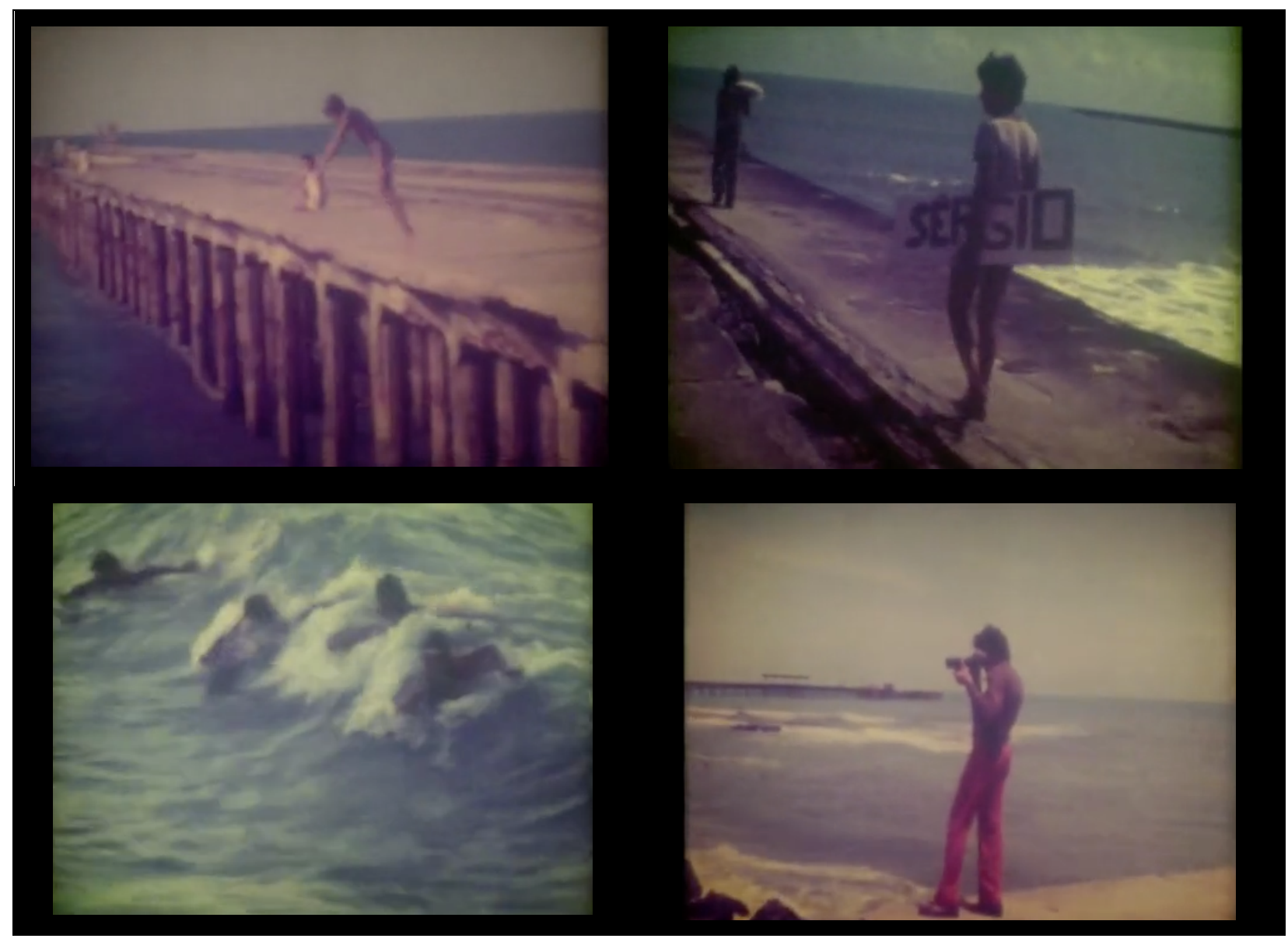

Imagem 1: Fotogramas da sequência de Supermemórias na Ponte dos Ingleses | (c) Filmagem de Hélio Rôla (1978) retomada por Danilo Carvalho em Supermemórias (2010)

As imagens que compõem essa sequência de Supermemórias pertencem, originalmente, aos únicos dois filmes Super-8 do acervo do cineasta amador Hélio Rôla, aos quais tivemos acesso. Apesar de serem poucos rolos, eles têm uma particularidade interessante: sua metragem é bastante superior à da maioria ${ }^{16}$ dos filmes Super-8 que compõem o material bruto de Supermemórias, eles têm, respectivamente: 11 minutos e 06 segundos; 22 minutos e 50 segundos. Mesmo sem termos tido acesso aos rolos originais (e, sim, apenas aos arquivos digitalizados), sabemos que a metragem superior desses dois rolos resulta da colagem de diferentes películas. Assim, pela duração total desses dois filmes, podemos concluir que Hélio filmou, pelo menos, 10 diferentes cartuchos Super-8, originalmente.

Graças às pistas arquitetônicas trazidas pelas imagens, identificamos que tal cenário é a Ponte dos Ingleses, construção localizada no

\footnotetext{
${ }^{16}$ A duração média de uma bobina Super-8 é de 3 1/3 minutos.
} 
bairro da Praia de Iracema, em Fortaleza. Já o segundo píer, presente no pano de fundo da imagem final, é a Ponte Metálica. Paralelas, as duas Pontes delimitam uma porção de mar onde, ainda hoje, formam-se ondas sedutoras para a realização de manobras aquáticas. Apesar de seus nomes, nenhuma das duas construções são, de fato, pontes, visto que não ligam dois pontos, mas, sim, avançam da calçada alguns metros em direção ao mar - por isso preferimos descrevê-las como píeres. Ambos os locais, na época dessas filmagens Super-8, estavam abandonados e com aspecto de ruínas, o que nos fala de um período de tempo específico em que suas histórias coincidiam. Isto porque, apesar de vizinhas e geograficamente paralelas, as duas pontes tiveram trajetórias opostas nas décadas seguintes. Enquanto a Ponte Metálica segue abandonada, a Ponte dos Ingleses foi reformada na década de 1990 e transformou-se em um dos principais pontos turísticos da cidade. Atualmente administrada pela Prefeitura Municipal de Fortaleza, a Ponte dos Ingleses é um local saneado, policiado e fiscalizado - o que inclui horários de funcionamento e regras que, inclusive, proíbem que se pule de cima dela para a água.

Ao assistirmos a esses dois filmes Super-8 de Hélio, percebemos que ambos são dedicados, inteiramente, ao registro de um campeonato esportivo informal realizado na Ponte dos Ingleses, em 1978. Sabemos disso porque os filmes originais trazem imagens, suprimidas pela montagem de Supermemórias, que, além de localizarem geográfica e temporalmente esse acontecimento, também permitem compreender a excepcionalidade do evento filmado. A sequência inicial de um desses filmes, por exemplo, é composta por uma série de planos curtos que reenquadram um cartaz e mostram, nessa ordem, as seguintes informações escritas: "Ponte 78"; "Campeonato Cearense de Carretilha"; e, por último: "Março dias 4 e 5 - Praia de Iracema".

Apesar do caráter introdutório da sequência inicial desse filme Super-8 de Hélio gerar uma expectativa de que seus registros seguiriam uma ordem cronológica e trariam uma narrativa organizada sobre o campeonato, isso não se verifica em nenhum de seus dois rolos. Ambos os filmes, na verdade, mostram uma sucessão de diferentes cenas que, claramente, fazem parte do mesmo contexto, mas não se apresentam em uma ordem lógica. Ou seja, não percebemos qualquer intenção de Hélio de narrar a evolução dos fatos ligados ao campeonato e, sim, de capturar situações que lhe chamavam a atenção dentre a multiplicidade de acontecimentos em torno do evento principal. Suas imagens nos mostram tanto algumas cenas ligadas às etapas e à organização do campeonato (tais como: saltos, cartazes, manobras aquáticas, o provável narrador do evento, um homem dando entrevista à imprensa etc.) quanto outras que parecem apenas acontecer no mesmo cenário e, até, disputar a atenção do público da competição (por exemplo: um helicóptero sobrevoando; pessoas vendendo lanches; moradores conversando apoiados nos muros de suas casas etc.). Verificamos que esses dois filmes de Hélio, assim como a maioria dos filmes de família, recitam fragmentos de ações (Odin 1995) - 
ou seja, mostram-se como uma coleção de acontecimentos pinçados pelo cineasta amador para serem transformados em imagem.

O desinteresse de Hélio em construir uma narrativa lógica sobre esse evento se evidencia ainda mais pelo fato dele ter dedicado três minutos (o que equivale a um rolo Super- 8 original inteiro) ao registro de uma briga entre dois homens que acontece na areia da praia, fora da área do campeonato (tanto que a filmagem acontece de longe). Esse acontecimento, imaginamos, pegou o cineasta amador de surpresa e por alguma razão lhe chamou a atenção. Entretanto, para um espectador que não conhece o contexto dessa filmagem, tais cenas representam um rompimento temático radical com o que vinha sendo mostrado até então - apesar do cenário se manter o mesmo e, logo após, voltarem às imagens dos mergulhadores e da Ponte dos Ingleses.

Quanto à forma de filmar desse cineasta amador, chama-nos atenção o excesso de planos em câmera lenta e com zoom em ambos os filmes, como se Hélio experimentasse livremente as possibilidades de seu equipamento. Percebemos, também, que ele procura interferir o mínimo possível nas situações filmadas e assume a postura de registrar as cenas à sua volta como um observador. Tanto que, na maior parte das cenas de seus filmes, as pessoas em cena sequer percebem que estão sendo filmadas. Obviamente, também há algumas tomadas em que o personagem filmado olha para e interage com a câmera e, em algumas outras, parece haver uma certa encenação a pedido do cineasta amador.

Ao entrevistarmos Hélio, descobrimos que ele foi um dos idealizadores desse Campeonato Cearense de Carretilha. Entretanto, sua filmagem não teve como intenção documentar o evento com o propósito de divulgá-lo. Hélio nos contou que esses filmes Super-8 não passavam de livres experimentações, apenas com o intuito de registrar os acontecimentos da vizinhança para, depois, exibir para as pessoas envolvidas. Eles nos parecem, assim, filmes de família - onde a "família”, nesse caso, é a comunidade em que esse cineasta amador se insere. Cabe relembrarmos que, conforme já aludido, Hélio não tinha o hábito de filmar sua família mas, sim, de apontar sua câmera para fora de casa e registrar, especialmente, festividades e eventos do bairro onde morava. Nesse sentido, a paisagem da Praia de Iracema ocupa o papel de um personagem importante em seus dois filmes que, por sua vez, adquirem valor de documento sobre esse local.

Ainda sobre o valor documental desse material, em um dos dois filmes aparecem em cena automóveis com as logomarcas de jornais e emissoras de rádio locais, denotando a cobertura jornalística do Campeonato Cearense de Carretilha (por mais informal que esse evento tenha sido). Em nossa pesquisa, encontramos uma matéria publicada no Jornal O Povo, em 6 de março de 1978, dia seguinte ao término do campeonato que, além de trazer algumas fotografias e uma breve explicação sobre as categorias da competição, também procura contextualizar o evento. Citamos um trecho: 
Toda a comunidade residente nas proximidades da velha ponte metálica (Praia de Iracema) deu sua contribuição para a realização do Campeonato Cearense de Carretilha (...) A competição, iniciada sábado, objetivou, basicamente, reviver a origem esportiva da comunidade (...). Embora o mar não seja mais tão violento, de grandes ondas, depois da construção de um dos espigões nas proximidades da ponte, a comunidade pretendeu reviver seu passado, relembrando seus antigos desportistas.

As informações trazidas por essa matéria de jornal, nos permitem vislumbrar uma nova camada de leitura das imagens desses dois filmes Super-8. Em primeiro lugar, nos chama a atenção o tom saudosista que o jornalista utiliza para descrever a motivação da realização comunitária deste evento - dedicado a celebrar uma prática que fora mais comum naquele local em tempos ainda mais remotos. Além disso, a reportagem relaciona a diminuição da prática da carretilha com o fato de o mar já não ser mais tão violento, "depois da construção de um dos espigões nas proximidades”. Redigido há quase quatro décadas, esse texto jornalístico ajuda a demonstrar a implicação de certas transformações urbanas na alteração ou mesmo na extinção de certos hábitos como parece ter sido o caso da carretilha. Mais que isso, essa matéria mostra que o incômodo sentido pela população ao testemunhar esse tipo de mudança motivou a realização de um campeonato como forma de celebrar uma prática esportiva outrora mais frequente.

Nesse sentido, é curioso observarmos que a organização informal do Campeonato Cearense de Carretilha, em certa medida, se assemelha à concepção do projeto do filme Supermemórias por Danilo Carvalho. Afinal, ambos os empreendimentos partem de iniciativas particulares de habitantes de Fortaleza e visam, cada um à sua maneira, a celebrar (e a recriar) partes da memória dessa cidade. Assim, nos parece cabível enxergar esse Campeonato para além do simples evento esportivo e, sobretudo, como um possível lugar de memória da Praia de Iracema e da cidade de Fortaleza. Interessante observar que o registro desse acontecimento em Super- 8 permitiu que ele sobrevivesse ao tempo e, anos mais tarde, pudesse servir à elaboração de um novo lugar de memória para a cidade, o filme Supermemórias.

Para finalizar a reflexão acerca desse trecho na Ponte dos Ingleses, cabe destacarmos que a sequência montada em Supermemórias nem mesmo insinua o contexto ao qual tais cenas se referem (o Campeonato Cearense de Carretilha). Pelo contrário, ela denota que tais imagens de saltos para o mar e de manobras aquáticas são registros de um fim de tarde qualquer na Ponte dos Ingleses. Afinal, a montagem realizada em Supermemórias prescinde de qualquer dado temporal e contextual, apesar do filme Super-8 original deixar claro de que evento se trata e, inclusive, as datas exatas em que ele ocorreu. Tal observação nos leva a compreender que, para compor esse novo lugar de memória para Fortaleza - representado pelo curta Supermemórias -, as imagens desses filmes Super-8 precisaram perder seu contexto original. Ou seja, a montagem de Supermemórias deixa de fora, justamente, as cenas que 
identificam o contexto em que se deu essa filmagem original e rearticula as imagens produzidas por Hélio de maneira que elas se desprendem de seu contexto específico e passam a representar apenas uma prática corriqueira naquele cenário da cidade. Entretanto, vimos que os saltos para o mar e a carretilha eram, de fato, práticas espontâneas da população de Fortaleza na época dessas filmagens. Isso significa dizer que, apesar de se referirem a um evento específico, as imagens que compõem essa sequência de Supermemórias poderiam, sim, ter sido capturadas em qualquer outro fim de tarde, daquela época. Portanto, percebemos que Carvalho cria um novo sentido com as imagens originais sem, contudo, abrir mão da verossimilhança na sequência montada.

\section{Conclusão}

Ao retomar imagens de filmes Super- 8 pertencentes a acervos familiares, percebemos que a realização do curta-metragem Supermemórias traz à tona o potencial de um material fílmico a princípio invisível ${ }^{17} \mathrm{pa}^{-}$ ra a produção cinematográfica contemporânea. Mais do que isso, ao tentar criar (de maneira poética) uma memória possível para Fortaleza, Carvalho nos faz ver que tais filmes são também vestígios do passado da cidade onde foram realizados. Com isso, podemos conceber o gesto criativo desse diretor como a elaboração de um novo lugar de memória para a capital cearense ao mesmo tempo que também constrói um lugar de memória para o próprio cinema - ao resgatar filmes amadores Super-8 de um exílio técnico. Nesse contexto, o presente artigo procurou apresentar reflexões sobre o processo pelo qual filmes amadores, produzidos na esfera particular, servem de elementos para a construção de lugares de memória. A partir da análise de dois filmes Super-8 originais em comparação às suas imagens reeditadas em uma nova sequência no filme Supermemórias, percebemos a montagem como procedimento cinematográfico da construção desse novo lugar de memória. Assim, para se atingir tal objetivo, mostra-se inevitável a reelaboração do sentido original dos filmes amadores.

Por fim, destacamos que nossa análise debruçou-se sobre um objeto de estudo original (dadas as especificidades de seu formato fílmico e de suas origens temporal e geográfica) buscando evidenciar que, justamente pela forma livre como foram filmados, esses filmes amadores podem ser retomados no presente como preciosos vestígios do passado, através dos mais diversos processos de retomada - sendo tanto o curta Supermemórias quanto a presente pesquisa duas dessas possibilidades.

\footnotetext{
${ }^{17}$ Por terem sido produzidos em um formato atualmente obsoleto e, além disso, estarem dispersos em acervos familiares. Invisíveis, portanto, no sentido quase literal da palavra.
} 


\section{BIBLIOGRAFIA}

Aasman, S. 1995. "Le film de famille comme document historique". In Le film de famille: usage privé, usage public, ed. Roger Odin, 97-111. Paris: Librairie des Méridiens Klincksieck e Cie.

Amorim, L. S. 2013. "Cinema e as Condições de Produção da Imagem em Super-8 na Paraíba: Aproximações Possíveis Entre Acervo Imagético e Memória”. In Cinema e memória: o Super-8 na Paraíba nos anos 1970 e 1980, ed. Lara Santos de Amorim e Fernando Trevas Falcone, 10-33. João Pessoa: Editora da UFPB.

Aragão, T. A. 2012. Doce som urbano: O triângulo e as territorializações dos vendedores de chegadinho em Fortaleza. Dissertação (Mestrado em Planejamento Urbano e Regional). Porto Alegre: Universidade Federal do Rio Grande do Sul.

Aragão, T. A. 2011. Como vendedores de chegadinho usam o som em seus percursos urbanos. 2011. Disponível em: http://www.ufrgs.br/gpit/wpcontent/uploads/2012/10/como-vendedores-de-chegadinhousam-o-som-em-seus-percursos-urbanos aragao-thais.pdf Acesso em: jan 2016.

Barbosa, M. C. 2007. "Memória: um passeio teórico". In Percursos do olhar: comunicação, narrativa e memória, ed. Marialva Carlos Barbosa, 39-52. Niterói: EdUFF.

Barthes, R. 2015. A câmara clara: nota sobre a fotografia. Rio de Janeiro: Nova Fronteira.

Bazin, A. 1991. “A Ontologia da Imagem Fotográfica”. In O Cinema: ensaios, ed. André Bazin, 19-26. São Paulo: Brasiliense.

Benjamin, W. 1985. "Sobre o conceito de história”. In: Obras Escolhidas, ed. Walter Benjamin, 222-234. São Paulo: Brasiliense.

Blank, T. Da tomada à retomada: origem e migração do cinema doméstico brasileiro. 2015. Tese (Doutorado em Comunicação e Cultura). Rio de Janeiro: Universidade Federal do Rio de Janeiro.

Charney, L. 2010. "Num instante: o cinema e a filosofia da modernidade”. In O Cinema e a Invenção da Vida Moderna, ed. Leo Charney e Vanessa R Schwartz, 317-334. São Paulo: Cosac Naify.

Diogo, L.A. 2010. Vídeos de família: entre baús do passado e telas do presente. Dissertação (Mestrado em Comunicação). Niterói: Universidade Federal Fluminense.

Furtado, B. e Araújo Lima, É. 2014. "Infiltrações e permanências do cinema”. Disponível em: http://www.compos.org.br/seer/index.php/ecompos/article/viewFile/1046/775. Acesso em: abr 2016. 
Holanda, F. 2014. "A era do super-8 no Ceará”. In Lua Cambará: Uma tragédia sertaneja, ed. Júlia Manta, 112-128. Fortaleza: Expressão Gráfica e Editora.

Lissovsky, M. 2005. "A memória e as condições poéticas do acontecimento". In: GONDAR, Jô; DODEBEI, Vera. In O que é Memória Social?, ed. Jô Gondar e Vera Dodebei, 133-144. Rio de Janeiro: Contracapa.

Nora, P. 1984. "Entre mémoire et histoire. La problématique des lieux". In Les lieux de mémoire, ed Pierre Norra, XVII-XLII. Paris: Éditions Gallimard.

Odin, R. 1995. "Le film de famille dans l'institution familiale". In Le film de famille: usage privé, usage public, ed. Roger Odin, 27-41. Paris: Librairie des Méridiens Klincksieck e Cie.

Odin, R. 1999. "La question de l'amateur". Communications Le cinéma en amateur 68: 47-89.

Pereira, A. M. M. 2010. A cultura amadora na virada do século XIX: a fotografia de Alberto de Sampaio (Petrópolis/Rio de Janeiro, 1888-1914. Tese (Doutorado em História Social). São Paulo: Universidade de São Paulo.

Recebido em 2016-01-01. Aceite para publicação em 2016-06-30. 